\title{
STRATEGI PEMANFAATAN MEDIA AUDIO VISUAL UNTUK PENINGKATAN HASIL BELAJAR BAHASA INGGRIS
}

\author{
Pari Purnaningsih \\ Program Studi Teknik Infomatika, Universitas Pamulang (Pari Purnaningsih) \\ email: dosen01028@unpam.ac.id
}

\begin{abstract}
ABSTRAK
Di dunia pendidikan, kemampuan berbahasa Inggris mahasiswa tak dapat dipisahkan dalam proses pembelajaran yang diberikan oleh dosen. Dosen sebagai fasilitator berusaha memberikan proses belajar mengajar yang terbaik untuk mahasiswanya. Bahasa Inggris merupakan mata kuliah yang mengembangkan keterampilan berkomunikasi baik secara lisan maupun tulisan, memahami dan mengungkapkan informasi. Mata kuliah ini tidak lagi sekedar mata kuliah yang terbatas pada ilmu tata bahasanya saja, namun juga dapat mengembangkan keterampilan mahasiswa dalam berkomunikasi bahasa Inggris secara lisan dan tulisan. Untuk itu diperlukan pendekatan kreatif yang dapat membawa mahasiswa lebih aktif dan menarik dalam pembelajaran bahasa Inggris. Salah satu proses pendekatan yang diberikan dosen adalah pembelajaran bahasa Inggris dengan memanfaatkan media audio visual, yaitu menggunakan video, film, dan musik. Dalam pengajaran materi bahasa Inggris, penggunaan media pembelajaran ini merupakan salah satu media pembelajaran yang tepat untuk digunakan. Tujuan jurnal ini adalah memberikan strategi dalam memanfaatkan media audio visual untuk meningkatkan hasil belajar bahasa Inggris mahasiswa. Secara teknis strategi pemanfaatan media audio visual dalam proses kegiatan belajar mengajar bahasa Inggris dibagai menjadi tiga tahapan, yaitu persiapan, penggunaan dan yang terakhir adalah tindak lanjut setelah penggunaan. Strategi pemanfaatan media ini akan menjadikan pembelajaran bahasa Inggris lebih efektif, interaktif dan menarik. Dosen akan lebih optimal dalam penyampaian materi dan mahasiswa menjadi lebih mudah memahaminya.
\end{abstract}

Keyword: Strategi, Media Audio Visual, Bahasa Inggris

\section{PENDAHULUAN}

Bahasa Inggris adalah salah satu bahasa internasional yang diajarkan secara luas di berbagai negara di dunia ini. Banyak penduduk di setiap negara memakai bahasa Inggris sebagai alat komunikasi dalam berbagai pertemuan penting pada tingkat internasional. Di Indonesia, bahasa Inggris adalah bahasa asing pertama yang dipelajari sebagai mata pelajaran wajib dari sekolah menengah pertama hingga perguruan tinggi. Salah satu upaya Pemerintah Indonesia dalam meningkatkan kemampuan bahasa Inggris adalah dengan memperkenalkan bahasa Inggris lebih awal di lembaga pendidikan formal, yakni dimulai dari sekolah dasar. Di dunia pendidikan perguruan tinggi, kemampuan berbahasa Inggris mahasiswa tak dapat dipisahkan dalam proses pembelajaran yang diberikan oleh dosen. Dosen sebagai fasilitator berusaha memberikan proses belajar mengajar yang terbaik untuk mahasiswanya. Salah satu proses pendekatannya yang diberikan dosen adalah menggunakan media pembelajaran. Media pembelajaran merupakan salah satu komponen pembelajaran yang mempunyai peranan penting dalam proses kegiatan belajar mengajar. Setiap dosen harus memanfaatkan media dalam setiap kegiatan pembelajaran. Oleh karena itu, dosen perlu mempelajari bagaimana menetapkan media yang tepat agar dapat mengefektifkan tujuan pembelajaran. Media pembelajaran mempunyai berbagai macam jenis yang bisa dipakai seperti, media visual, media audio, media audio visual, media cetak dan lain-lain. Dari berbagai macam jenis media pembelajaran, media audio visual merupakan media yang bisa diterima oleh indera penglihatan dan pendengaran. Bahasa Inggris merupakan mata kuliah yang mengembangkan keterampilan berkomunikasi baik secara lisan maupun tulisan, memahami dan mengungkapkan informasi. Dalam penyampaian materi bahasa Inggris, media audio visual merupakan media yang tepat untuk digunakan. Proses kegiatan belajar mengajar (KBM) akan menjadi lebih efektif, interaktif dan menarik. Dosen menjadi lebih optimal dalam menyampaikan isi materi dan mahasiswa menjadi lebih mudah memahaminya. Dengan menggunakan media pembelajaran audio visual, mahasiswa dapat langsung melihat dan meniru pengucapan 
kosakata atau ungkapan bahasa Inggris. Salah satu contohnya dalam pengajaran speaking (berbicara), Dosen menyajikan sebuah video percakapan bahasa Inggris dengan menggunakan alat proyektor dan pengeras suara. Proses kegiatan belajar mengajar bahasa Inggris pun tidak lagi membosankan bagi mereka. Mahasiswa menjadi lebih termotivasi untuk belajar bahasa Inggris. Berdasarkan uraian diatas bahwa salah satu upaya meningkatkan keberhasilan belajar Inggris mahasiswa dapat dilakukan melalui pemanfaatan media pembelajaran audio visual.

\section{PEMBAHASAN}

\section{A. Media pembelajaran}

Media pembelajaran secara umum adalah alat peraga atau alat bantu dalam proses belajar dan mengajar. Media pembelajaran dapat berupa buku, suara, gambar video dan sebagainya. Media pembelajaran digunakan untuk meningkatkan hasil belajar yang lebih baik. Arsyad (2014:3) mengemukakan bahwa "pengertian media dalam proses belajar mengajar adalah alat-alat untuk menangkap, memproses, dan menyusun kembali informasi yang disampaikan. Dalam pengertian ini, guru, buku teks, dan lingkungan sekolah merupakan media pembelajaran".

Zhamarah dan Zain (2006:120) menjelaskan bahwa "media pembelajaran merupakan alat bantu apa saja yang dapat dijadikan sebagai penyampai informasi belajar atau penyalur pesan guna mencapai tujuan pengajaran. Media dapat mewakili apa yang kurang mampu dosen atau guru ucapkan melalui kata-kata atau kalimat tertentu". penerimanya dapat melakukan proses belajar secara efisien dan efektif".

Dari pernyataan-pernyataan yang telah diuraikan di atas, dapat disimpulkan bahwa media pembelajaran terdiri atas dua unsur penting, yaitu perangkat dan unsur pesan yang dibawanya. Perangkat adalah sarana atau peralatan yang digunakan untuk menyajikan bahan ajar atau pesan. Unsur pesan adalah informasi atau bahan ajar yang akan disampaikan kepada peserta didik.

\section{B. Fungsi Media Pembelajaran}

Media pembelajaran digunakan untuk memberikan kemudahan kepada mahasiswa dalam memahami materi. Proses pembelajaran akan lebih bervariasi, tidak semata-mata komunikasi verbal melalui penuturan kata-kata dosen, sehingga mahasiswa tidak merasa bosan dan dosen tidak kehabisan tenaga.
Menurut Rusman (2011:172), salah satu fungsi media pembelajaran dalam proses pembelajaran adalah pembelajaran akan lebih menarik perhatian mahasiswa sehingga dapat menumbuhkan semangat belajar dan materi pembelajaran akan lebih jelas maknanya sehingga dapat lebih dipahami dan memungkinkan mahasiswa menguasai tujuan pembelajaran lebih baik.

Sanjaya (2016:70) menjelaskan bahwa media pembelajaran bermanfaat untuk menangkap suatu objek atau peristiwa-peristiwa tertentu yang dapat diabadikan dengan foto, film atau direkam melalui video atau audio kemudian disimpulkan dan dapat digunakan saat diperlukan.

Susilana dan Riyana (2009:13) menyebutkan beberapa manfaat media pembelajaran secara umum adalah untuk memperjelas pesan, mengatasi keterbatasan ruang, waktu, tenaga dan daya indera dan menimbulkan gairah belajar.

Berdasarkan uraian di atas, maka dapat disimpulkan bahwa fungsi media pembelajaran adalah untuk memudahkan dosen atau fasilitator memberikan materi, menarik perhatian mahasiswa dan menciptakan proses belajar mengajar yang lebih menarik.

\section{Dasar Pertimbangan Pemilihan Media. Alasan teoritis pemilihan media}

Setiap media pembelajaran memiliki kelebihan dan kelemahan masing-masing, untuk itu pemilihan dan penggunaan media pembelajaran harus sesuai dengan kebutuhan mahasiswa dan tujuan pembelajaran. Hal ini dimaksudkan untuk menghindari kesalahan pemilihan media yang akan menjadi penghalang proses belajar mengajar.

Suyanto dan Jihad (2013:105) mengemukakan bahwa prinsip pertimbangan dalam pemilihan media pembelajaran bergantung pada tujuan pembelajaran, materi pelajaran, strategi belajar-mengajar dan kondisi kelas. Pemilihan media pembelajaran yang tepat dapat mempercepat tujuan pembelajaran. Apakah media pembelajaran tersebut mampu meningkatkan kecerdasan kognitif, afektif dan psikomotoris yang merupakan tujan pembelajaran.

Suprihatiningrum (2013:324) berpendapat tentang beberapa pertimbangan dalam memilih media pembelajaran yang tepat antara lain adalah tujuan pembelajaran, metode pembelajaran, karakteristik materi pembelajaran, kegunaan 
media pembelajaran dan kemampuan dosen dalam menggunakannya. Media pembelajaran biasanya digunakan dosen untuk membantu mahasiswa memahami materi pelajaran yang diajarkan. Untuk itu media pembelajaran yang digunakan haruslah sesuai dengan materi pelajaran yang diajarkan kepada mahasiswa.

Dengan menggunakan media pembelajaran maka akan mempermudah dosenu dalam menerapkan strategi mengajar. Penggunaan media pembelajaran dan penerapan strategi pengajaran yang tepat akan meningkatkan hasil belajar mahasiswa. Penggunaan media pembelajaran akan membantu dosen pada kondisi kelas tertentu. Dosen yang mengajar pada kelas berjumlah siswa banyak dapat menggunakan media audio visual. Penggunanaan media audio visual dapat mempermudah dosen untuk memperjelas materi yang disampaikannya.

Menentukan media yang cocok digunakan dalam pembelajaran haruslah disesuaikan dengan tujuan, strategi, waktu yang tersedia dan fasilitas pendukung lainnya. Dengan demikian alasan teoritis menjadi dasar pemilihan media pembelajaran yang memiliki kesesuaian dengan tujuan (specification objective), kesesuaian dengan isi (specification of content), strategi pembelajaran (determination of strategy) dan waktu yang tersedia (alocation of time).

Dari uraian di atas menggambarkan dengan jelas bagaimana kedudukan media pembelajaran yang tidak dapat dipisahkan dari keseluruhan komponen sistem pembelajaran. Penggunaan media pembelajaran yang tepat akan meningkatkan hasil belajar mahasiswa. Dengan demikian pemilihan media pembelajaran menjadi sangat penting dan menjadi alasan teoritis pemilihan media dalam pembelajaran.

\section{Alasan praktis pemilihan media}

Pembelajaran yang efektif membutuhkan perencanaan yang baik. Media pembelajaran yang akan digunakan juga memerlukan perencanaan yang baik. Meskipun demikian, kenyataan di lapangan menunjukkan bahwa seorang dosen memiliki alasan praktis dalam memilih salah satu media pembelajaran di kelas.

Alasan praktis berkaitan dengan beberapa pertimbangan dan alasan dari pengguna, seperti guru, dosen dan instuktur dalam memilih media yang akan digunakan. Sadiman (1996:84) menjelaskan bahwa terdapat beberapa penyebab orang memilih media, antara lain alat demonstrasi, keterbiasaan dan memotivasi siswa.
Arysad (2017:67) menyebutkan tiga alasan praktis seorang dosen dalam memilih media pembelajaran antara lain adalah (1) dosen merasa sudah akrab dengan media pembelajaran yang digunakan, (2) dosen merasa bahwa media yang dipilihnya dapat mewakili dengan lebih baik daripada dirinya sendiri, (3) media yang dipilihnya dapat menarik minat dan perhatian mahasiswa.

Berdasarkan faktor-faktor diatas, dapat disimpulkan bahwa alasan praktis dosen atau fasilitator memilih media pembelajaran dikelas adalah karena keterbiasaan, dapat mendemostrasikan materi dan menciptakan pembelajaran yang lebih aktif.

\section{Penggunaan Media Audio Visual Dalam Pembelajaran}

Media pembelajaran mempunyai berbagai macam jenis yang bisa dipilih dan digunakan di kelas seperti, media visual, media audio, media audio visual, media cetak dan lain-lain. Dari berbagai macam jenis media pembelajaran, media audio visual merupakan media yang bisa diterima oleh indera penglihatan dan pendengaran.

Media audiovisual pada hakikatnya adalah media perantara atau penggunaan materi dimana penyerapannya melalui pengindraan penglihatan dan pendengaran yang bertujuan untuk mempertunjukkan pengalaman-pengalaman pendidikan yang nyata kepada siswa (Duludu, 2017:51). Cara ini dianggap lebih tepat, cepat dan mudah dibandingkan dengan melalui pembicaraan, pemikiran dan cerita mengenai pengalaman pendidikan.

Arysad (2017:50) menyebutkan salah satu jenis media pembelajaran audio visual yaitu film dan video. Sama halnya dengan film, video dapat menggambarkan suatu objek yang bergerak bersama-sama dengan suara alamiah atau suara yang sesuai. Kemamampuan film dan video melukiskan gambar hidup dan suara memberikan daya tarik tersendiri. Kedua-duanya dapat menyajikan informasi, memaparkan proses, menjelaskan konsep-konsep yang rumit, mengajar keterampilan, menyingkat atau memperpanjang waktu, dan mempengaruhi sikap. Beberapa keuntungan film dan video dalam pembelajaran antara lain:

1. Film dan video dapat melengkapi pengalaman-pengalaman dasar dari siswa ketika mereka membaca, berdiskusi, dan berpraktik. 
2. Film dan video dapat menggambarkan suatu proses secara tepat yang dapat disaksikan secara berulang-ulang jika dipandang perlu. Misalnya, langkahlangkah dan cara mengucapkan kosakata bahasa Inggris (pronounciation).

3. Di samping mendorong dan meningkatkan motivasi, film dan video menanamkan sikap dan segi-segi afektif lainnya.

4. Film dan video dapat menyajikan peristiwa yang berbahaya bila dilihat secara langsung seperti lahar gunung merapi atau perilaku binatang buas.

Dalam hal pengajaran bahasa Inggris, penggunaan media pembelajaran audio visual merupakan pilihan media yang tepat. Hal ini karena bahasa Inggris merupakan pelajaran yang mengembangkan keterampilan berkomunikasi baik secara lisan maupun tulisan, memahami dan mengungkapkan informasi. Dengan menggunakan media pembelajaran audio visual, mahasiswa dapat langsung melihat dan meniru pengucapan kosakata atau ungkapan bahasa Inggris. Salah satu contohnya dalam pengajaran speaking (berbicara), Dosen menyajikan sebuah video percakapan bahasa Inggris dengan menggunakan alat proyektor dan pengeras suara. Proses kegiatan belajar mengajar bahasa Inggris pun tidak lagi membosankan bagi mereka. Mahasiswa menjadi lebih termotivasi untuk belajar bahasa Inggris.

\section{E. Strategi Pemanfaatan Media Audio Visual Dalam Pembelajaran.}

Tahapan persiapan.

Tahapan ini dilakukan untuk menyiapkan jenis media audio visual seperti apa yang akan digunakan dalam pembelajaran bahasa Inggris. Untuk itu ada beberapa hal yang perlu diperhatikan, yaitu:

a. Karakteristik peserta didik.

Seorang dosen atau pengajar harus mengetahui karakteristik peserta didiknya.

Diantaranya adalah usia, level kecerdasan, dan kebutuhan mereka. Semua itu dilakukan untuk memastikan efektifitas penggunaan media pembelajaran.

b. Merumuskan tujuan pembelajaran.

Langkah ini bertujuan untuk menentukan, dan merumuskan tujuan pembelajaran yang ingin dicapai. Tujuan yang ingin dicapai adalah aspek kognitif, aspek afektif dan aspek psikomotorik. Aspek kognitif (knowledge) adalah aspek kemampuan yang berhubungan dengan berpikir, mengetahui dan memecahkan masalah. Aspek afektif (values) adalah kemampuan yang berhubungan dengan sikap, nilai, minat, dan apresiasi. Dan yang ketiga adalah aspek psikomotorik, aspek yang berkaitan dengan keterampilan (skill) yang bersifat manual atau motorik.

c. Mendesain materi dan media yang tepat.

Materi dan media pembelajaran yang akan digunakan sebaiknya didesain menjadi lebih efektif. Hal ini bertujuan untuk mencegah terbuangnya waktu, tenaga dan biaya. Hal lain yang perlu diperhatikan adalah apakah materi dan media itu akan mampu meningkatkan minat mahasiswa dalam kegiatan belajar dan mengajar.

d. Tahap percobaan media.

Tahapan terakhir dalam persiapan adalah percobaan media sebelum digunakan. Alasan yang mendasari percobaan ini adalah untuk menghindari terjadinya sesuatu yang tidak diinginkan, misalnya film atau video tidak dapat diputar, suara tidak terdengar dan sebagainya. Apabila itu semua terjadi, tentu dapat menyulitkan dosen tersebut dan juga dapat menimbulkan keributan di dalam kelas.

Tahapan penggunaan media audio visual dalam pembelajaran bahasa Inggris.

Setelah keempat tahapan persiapan di atas selesai ditentukan. Tahapan selanjutnya adalah perlu dipersiapkan kelas atau ruang pembelajaran yang kondusif seperti tempat duduk mahasiswa, meja, sumber listrik, layar, proyektor, pengeras suara, penerangan, ventilasi udara dan lainlainnya. Hal lainya yang dapat dosen lakukan adalah meminta ke mahasiswa untuk bekerja sama dalam menciptakan suasana ruang kelas yang kondusif demi tercapainya tujuan hasil belajar.

\section{a. Pembelajaran kompetensi mendengarkan (listening skill)}

Setiap mahasiswa menginginkan mereka dapat memahami apa yang diucapkan penutur bahasa Inggris, baik secara bertatap muka, di program acara TV atau siaran radio, film dan musik. Itulah salah satu alasan mereka belajar mendengarkan dalam bahasa Inggris. Mendengarkan sangat baik bagi mahasiswa untuk 
belajar pengucapan bahasa Inggris yang baik dan benar. Dengan mendengarkan mereka dapat belajar dengan tepat tentang intonasi dan juga penekan setiap kata-kata bahasa Inggris.

Media audio seperti radio, tape dan CD player dapat digunakan dalam semua fase pembelajaran mulai dari penghantar sampai kepada evaluasi belajar. Penggunaan media ini sangat mendukung sistem pembelajaran tuntas (mastery learning). Materi pelajaran listening skill dari rekaman percakapan bahasa Inggris langsung dari penutur asli dapat diperoleh dosen dari berbagai sumber, seperti internet, musik dan $\mathrm{CD}$ audio listening.

Beberapa prinsip-prinsip di bawah dapat digunakan dalam pembelajaran mendengarkan (listening skill):

1. Tuntun mahasiswa untuk mendengarkan sesering mungkin.

Semakin sering mahasiswa mendengarkan akan semakin baik pemahaman mereka tentang pengucapan dan menggunakannya dengan tepat. Saat proses pembelajaran listening, tuntun mahasiswa untuk menjalani pengalaman mendengar dengan waktu yang tepat atau dengan sedikit penundaan antara pengantar dan mulainya proses listening. Pastikan mahasiswa untuk mendengarkan dengan tenang, pusatkan perhatikan kepada materi audio, dan menghubungkan apa yang didengar dengan pernyataan-pernyataan yang dibahas sebelum pembelajaran dimulai.

2. Bantu mahasiswa untuk menyiapkan materi mendengarkan (listening materials).

Kebutuhan materi bahan ajar mendengarkan harus sudah disiapkan oleh dosen. Mereka akan membutuhkan gambar-gambar (visuals), pertanyaanpertanyaan (questions) dan topik (topics) yang akan dipelajari. Kebutuhan ini diperlukan mahasiswa untuk memprediksi setiap jawaban soal.

3. Putar kembali bagian-bagian materi listening yang belum dikuasi oleh mahasiswa yang belajar lamban.

4. Bimbing mahasiswa untuk merespon isi dari materi mendengarkan, bukan hanya dari bahasanya atau kosakatanya.

Seperti yang telah diungkapkan diatas bahwa media audio dapat pula dijadikan kegiatan belajar dirumah. Untuk membuat kegiatan listening di luar kelas atau di rumah lebih efektif dan produktif, berbagai teknik dapat digunakan, antara lain:

1. Berikan tugas kepada mahasiswa untuk mendengarkan pidato atau percakapan bahasa Inggris, kemudian buat pertanyaanpertanyaan yang menyangkut fakta berdasarkan apa yang didengar.

2. Tugaskan kepada mahasiswa untuk mengidentifikasi berbagai unsur, seperti pembicara, waktu dan peristiwa yang terjadi dari rekaman drama bahasa Inggris.

3. Mintahlah mahasiswa untuk mendengarkan lagu-lagu berbahasa Inggris dan ceritakan kembali makna apa yang didapat dari lirik lagu tersebut dengan menggunakan bahasa Inggris.

4. Tugaskan kepada mahasiswa untuk menonton film dengan terjemahan (English subtitle) bahasa Inggris, kemudian ceritakan kembali cerita singkat dari film itu (retelling).

\section{b. Pembelajaran kompetensi berbicara (speaking skill).}

Kemampuan mahasiswa berbicara bahasa Inggris tergantung kebiasaan meraka berbicara di kelas dan menjadikan kelas mereka menjadi kelas bahasa (English Classroom). Dengan kata lain, kepercayaan diri mereka dalam berbahasa Inggris harus ditingkatkan.

Media film atau video dapat digunakan oleh dosen untuk meningkatkan kompetensi berbicara (speaking skill). Sumber bahan ajar atau materi ini bisa diperoleh atau diunduh dari internet atau youtube. Di bawah ini beberapa aktivitas pembelajaran berbicara bahasa Inggris menggunakan mediafilm, anta lain:

1. Putarkan video singkat dengan tema yang sudah ditentukan.

Contoh tema video yang diambil adalah tentang wawancara seorang artis atau bintang film (talkshow). Buat beberapa kelompok belajar masing-masing empat mahasiswa. Setiap anggota kelompok mencoba berperan menjadi artis dan pembawa acara. Pastikan mahasiswa yang lainnya menjadi penonton yang dapat mengajukan pertanyaan ke bintang tamunya (guest star) dan dosen dapat menjadi sutradara di acara tersebut. Peran dosen sebagai pengatur irama aktifitas percakapan kapan diakhiri dan dilanjutkan. Aktifitas ini lebih dikenal dengan sebutan role-play 
2. Putarkan video atau film singkat tanpa suara (play video without sound).

Dosen dan mahasiswa mendiskusikan apa saja yang mereka lihat dan petunjukpetunjuk apa yang didapatkan dan juga beberapa karakter yang mereka tebak. Setelah itu mereka menjawab beberapa pertanyaan yang sudah disiapkan dosen. Sebagai contoh, dosen memutarkan video tentang dua orang yang sedang belanja di toko. Video diputar tanpa menggunakan suara dan terjemahan. Setelah itu, dosen memberikan beberapa pertanyaan seperti, what are they talking about?, what do they want to buy?, why do they buy in this store? dan pertanyaan lainnya. Pembelajaran ini dapat dilakukan perkelompok ataupun individu.

3. Dosen memberikan beberapa pilihan judul film popular (box office) kepada mahasiswa yang pernah mereka tonton. Selanjutnya, mereka memilih judul film apa yang paling difavoritkan dikelas. Dosen membagikan format kuisener atau lembar pertanyaan kepada mahasiswa. Perintahkan mereka untuk mendiskusikan pertanyaan-pertanyaan yang terdapat di lembar kuisener. Variasi pertanyaan dapat dikembangkan dengan menggunakan formula "what, where, when, who, why and why", yaitu who is your favorite actor, when did you watch this film, what did you think about this film?. Di bawah ini contoh format tabel kuisener:

Tabel 1. Kuesioner Media Film

\begin{tabular}{|c|c|c|}
\hline Judul & Ceklis bila & Bagus (y) \\
Film & Pudah (vv) \\
& menonton & Buruk (x) \\
& Sangat Buruk (xx) \\
\hline & & \\
\hline & & \\
\hline & & \\
\hline & & \\
\hline
\end{tabular}

Aktifitas diskusi akan berlangsung aktif di dalam kelas karena mahasiswa merasa tertarik mendiskusikan tentang film. Kegiatan ini sebaiknya dilakukan perkelompok dan setiap kelompok bisa berdiskusi dengan kelompok lainnya.

\section{c. Pembelajaran kompetensi menulis (writing skill).}

Menulis merupakan aktifitas seseorang yang ditampilkan dalam bentuk tulisan untuk memberikan informasi. Di dalamnya terkandung topik tertentu yang ingin disampaikan kepada pembaca. Seorang penulis harus melaksanakan beberapa tahapan yang secara umum terdiri atas perencanaan (planning/ pre writing), pembuatan konsep tulisan (drafting), dan perbaikan (revising). Untuk itu sejumlah teknik atau strategi dapat diterapkan oleh dosen di ruang kelas untuk pembelajaran keterampilan menulis yang menarik dan berkualitas.

Srategi pembelajaran menulis dapat menggunakan media lagu. Media ini sangat baik untuk mendorong kemampuan mahasiswa menulis. Dosen dapat memutar lagu dengan lirik berbahasa Inggris dan menuntun mahasiswa untuk mengimajinasikan dan menuliskan apa yang mereka telah dengar, seperti tema, pesan dan cerita dari lagu itu. Strategi ini diterapkan untuk pembelajaran menulis bebas (writing freely).

Missing lyrics, strategi ini dapat digunakan untuk memberikan semangat positif kepada mahasiswa dalam pembelajaran menulis bebas. Sebelum melaksanakan strategi ini, dosen harus mempersiapkan lirik lagu yang sesuai dengan kebutuhan materi ajar mahasiswa. Lirik tersebut dihilangkan beberapa kata atau phrase dan selanjutnya diberikan ke seluruh mahasiswa di kelas.

Pastikan suasana kelas dalam keadaan kondusif sebelum dosen memutar lagunya. Saat proses berlangsung, dosen cukup memutar lagu dua kali dan beri waktu yang cukup kepada mahasiswa untuk mengisi jawaban beberapa kata atau phrase lirik yang hilang.

Dua strategi di atas dilakukan untuk mendorong semangat positif kepada mahasiswa dalam pembelajaran menulis. Strategi selanjutnya adalah mendorong mahasiswa untuk menulis sesuai dengan tahapan-tahapan yang terdiri atas perencanaan (planning/ pre writing), pembuatan konsep tulisan (drafting), dan perbaikan (revising). Langkah pertama adalah ide atau rencana. Untuk membantu mahasiswa menemukan ide tulisan, mahasiswa dapat memulai dengan kata tanya " $5 \mathrm{Wh}$ dan How". Langkah kedua adalah konsep tulisan. Langkah ini adalah kelanjutan dari pengembangan katakata kunci yang telah ditulis pada langkah pertama menjadi draft karangan, sebagai contoh hasil dari kata tanya who. Dari kata who, 
mahasiswa dapat memulai konsep tulisan yang menceritakan tentang seseorang. Dilanjutkan dengan kata tanya what, bisa dikembangkan menjadi tulisan yang menceritakan karakter, pekerjaan dan aktifitasnya. Langkah ketiga adalah perbaikan (editing). Biasanya kesalahan terdapat pada kata, frase atau kalimat. Kesalahan ini dapat diperiksa dan juga didiskusikan bersama-sama mahasiswa lainnya.

\section{d. Pembelajaran kompetensi membaca (reading skill).}

Kebiasan membaca teks (reading skill habit) sangat bermanfaat untuk kemahiran berbahasa. Membaca juga membawa dampak positif terhadap pengetahuan kosakata (vocabulary), pengucapan (spelling) dan menulis (writing) bagi mahasiswa. Manfaat lain dari membaca adalah dapat menghasilkan ketertarikan terhadap topik tulisan dan mendorong untuk mendiskusikannya.

Membaca terbagi atas dua perbedaan tujuan, yaitu umum dan khusus (extensive and intensive). Membaca untuk tujuan umum biasanya membaca pada hal-hal yang disukai pembacanya (joyful reading), seperti membaca novel, koran, majalah dan internet (web pages). Dan yang kedua adalah tujuan khusus dari membaca, dimana pembacanya fokus terhadap kontruksi teks atau tulisan. Kemampuan membaca inilah yang dipelajari mahasiswa disetiap kampusnya. Mahasiswa biasanya diminta untuk mempelajari jenis-jenis teks (genre texts), makna teks (meaning texts), tata bahasa (grammar) dan kosakata (vocabulary).

Untuk itu dalam pembelajaran membaca, tidak terlepas dari dua tujuan yang sudah dijelaskan di atas. Seorang dosen sudah seharusnya mendorong mahasiswanya untuk menjadikan membaca menjadi sebuah kebiasaan. Semakin banyak mahasiwa membaca, semakin luas pengetahuan yang didapat mereka.

Di bawah ini beberapa strategi pembelajaran membaca (reading skill) yang dapat digunakan oleh dosen demi tercapainya hasil belajar yang maksimal, diantaranya:

1. Summarize the story.

Strategi ini bisa digunakan dengan cara memberikan beberapa kisah cerita rakyat pendek atau dongeng (folktales). Perintahkan mahasiswa untuk membuat kelompok yang beranggotakan tiga orang dan memilih satu judul dongeng, selanjutnya suruh mereka membacanya didepan kelas. Setelah selesai membaca, tugaskan mereka untuk mendiskusikan dan menganalisis tentang karakter (characters), setting, masalah (problem), solusi (solution) dan pesan (messages). Dosen dapat membimbing mereka dalam menganalisanya.

2. Using article.

Pembelajaran ini menggunakan artikelartikel yang didapat dari koran (newspaper), majalah (magazine) dan internet (webpages). Tugaskan mahasiswa untuk mencari artikel berbahasa Inggris dan menganalisanya. Yang dapat dianalisa antara lain, jenis teks (genre text), kosakata (vocabulary) dan tata bahasa (grammar). Persentasikan hasil analisis mereka di kelas.

3. Following intructions.

Dosen memberikan beberapa potongan kertas yang bertuliskan intruksi pengoperasian sederhana (simple intructions text) seperti, resep makanan, memasang tinta printer dan lainnya. Berikan juga gambar-gambar yang sesuai dengan instruksinya. Setelah mereka mendapatkannya, cocokkan intruksi tersebut dengan gambar-gambarnya. Kemudian susun intruksi-intruksi itu menjadi sebuah teks intruksi yang benar.

Strategi-strategi diatas bukan merupakan hal yang baku dalam pembelajaran bahasa Inggris, semua itu kembali kepada situasi dan kondisi disetiap kelasnya. Perlu adanya kreatifitas dosen mengenai strategi pembelajaran dan kerjamasa dengan mahasiswa dalam proses belajar dan mengajar. Penggunaan setiap strategi pembelajaran tentunya harus sudah dipelajari, dipahami dan diaplikasikan ke proses pembelajaran. Selanjutnya, diakhir pembelajaran harus ada peninjaun hasil (review) mengenail capaian tujuan suatu pembelajaran. Dan pembelajaran pun akan menghasilkan tujuan pembelajaran yang berkualitas.

\section{Tahapan tindak lanjut (follow up)}

Kegiatan ini merupakan tahapan tindak lanjut dari persiapan dan pelaksanaan yang sudah dijalankan. Tahapan ini bertujuan untuk mengetahui sejauh mana persiapan, proses dan hasil dari pembelajaran, apakah sudah baik, efektif dan sesuai dengan yang sudah direncanakan. Untuk itu diperlukan soal tes atau ujian kepada mahasiswa tentang apa yang sudah 
dipelajari dan juga mendiskusikan tentang proses pembelajaran kepada mahasiswa.

Sesuai penjelasan di atas, bukti-bukti hasil dari kegiatan tindak lanjut ini bisa dapat diperoleh dengan dua aspek, yaitu bukti lembar format nilai tes dan kontribusi media terhadap keberhasilan proses pembelajaran dalam bentuk kuisener. Di bawah ini, contoh format kuisener tentang kontribusi media terhadap keberhasilan pembelajaran.

Tabel 2. Evaluasi Kontribusi Media Audio Visual Terhadap Keberhasilan Pembelajaran Nama :

Tanggal :

\begin{tabular}{|c|c|c|c|c|}
\hline \multirow{2}{*}{$\mathrm{N}$} & \multirow{2}{*}{ Pertanyaan } & \multicolumn{2}{|c|}{$\begin{array}{l}\text { Adakah pengaruh media audio } \\
\text { visual terhadap pembelajaran }\end{array}$} & \multirow{2}{*}{$\begin{array}{c}\text { Alasan } \\
\text { bila tidak }\end{array}$} \\
\hline & & Iya & Tidak & \\
\hline 1 & $\begin{array}{l}\text { Apakah penggunaan media audio visual memberikan } \\
\text { pengaruh positif terhadap mata kuliah listening }\end{array}$ & & & \\
\hline 2 & $\begin{array}{l}\text { Apakah penggunaan media audio visual memberikan } \\
\text { pengaruh positif terhadap mata kuliah speaking }\end{array}$ & & & \\
\hline 3 & $\begin{array}{l}\text { Apakah penggunaan media audio visual memberikan } \\
\text { pengaruh positif terhadap mata kuliah writing }\end{array}$ & & & \\
\hline 4 & $\begin{array}{l}\text { Apakah penggunaan media audio visual memberikan } \\
\text { pengaruh positif terhadap mata kuliah reading }\end{array}$ & & & \\
\hline \multicolumn{5}{|c|}{ Saran anda: } \\
\hline
\end{tabular}

\section{KESIMPULAN}

Mata kuliah bahasa Inggris merupakan mata kuliah yang mengembangkan keterampilan berkomunikasi baik secara lisan maupun tulisan, memahami dan mengungkapkan informasi. Untuk itu diperlukan strategi pembelejaran yang efektif agar dapat membawa mahasiswa lebih aktif dan menarik dalam pembelajaran bahasa Inggris. Salah satu proses pendekatan yang diberikan dosen adalah pembelajaran bahasa Inggris dengan memanfaatkan media audio visual, yaitu menggunakan video, film, dan musik. Dalam pengajaran materi bahasa Inggris, penggunaan media pembelajaran ini merupakan salah satu media pembelajaran yang tepat untuk digunakan. Setidaknya ada tiga tahapan yang harus dijalankan oleh seorang dosen untuk menerapkan strategi pemanfaatan media audio visual dalam pembelajaran bahasa Inggris, yaitu:

a. Persiapan pembelajaran

b. Proses pembalajaran

c. Tindak lanjut pembelajaran.

Jika ketiga tahapan itu dilaksanakan dengan baik, maka tujuan pembelajaran pun akan maksimal.

\section{DAFTAR PUSTAKA}

Arysad, A. (2017). Media pembelajaran. Jakarta: Rajawali Press.

Djamarah, B.A., \& Zain, A. (2012). Strategi belajar mengajar. Jakarta: Rineka Cipta.

Susilana, R., \& Riyana, C. (2009). Media pembelajaran. Bandung: Wacana Prima.

Asyar, R. (2012). Kreatif mengembangkan media pembelajaran. Jakarta: Gaung Persada Press

Rusman. (2012). Model-model pembelajaran. Jakarta: Rajawali Press.

Sanjaya, W (2012). Media komunikasi pembelajaran. Jakarta : Kencana Prenada Media Group.

Suyanto, \& Jihad, A. (2013) Menjadi guru profesional. Jakarta: Erlangga.

Suprihatiningrum, J (2013). Strategi pembelajaran teori \& aplikasi. Yogyakarta: Ar-Ruzz Media

Sadiman, A. (1996). Media pendidikan. Jakarta: PT. Raya Grafindo Persada.

Harmaer, J. (2007). The practice of English language teaching. Cambridge: Pearson Education.

Harmaer, J. (2007). How to teach English new edition. Cambridge: Pearson Education. 